\title{
Metals in the shell of Bathymodiolus azoricus from a hydrothermal vent site on the Mid-Atlantic Ridge
}

\author{
A. Cravo ${ }^{\text {a,* }}$, P. Foster ${ }^{\text {b }}$, C. Almeida ${ }^{\text {a }}$, R. Company ${ }^{\text {a }}$, R.P. Cosson ${ }^{\text {c }}$, M.J. Bebianno ${ }^{\text {a }}$ \\ ${ }^{a}$ Centre of Marine and Environmental Research (CIMA), FCMA, University of Algarve, Campus de Gambelas, 8005-139 Faro, Portugal \\ ${ }^{\mathrm{b}}$ School of Ocean Sciences, University of Wales, Bangor, Gwynedd LL59 5EY, UK \\ ${ }^{\mathrm{c}}$ ISOMer - UPRES-EA 2663, Laboratoire de Biologie Marine, Faculté des Sciences et Techniques, Université de Nantes, BP 92208, F-44322 Nantes, France
}

Received 16 October 2006; accepted 3 January 2007

\begin{abstract}
Specimens of the mussel Bathymodiolus azoricus were collected from Menez Gwen, a relatively shallow (850 m) hydrothermal vent field on the Mid-Atlantic Ridge. Each bivalve shell $(n=21)$ was individually cleaned by selective chemical. The residual crystal matrix of each shell was individually analysed for the concentrations of the minor elements magnesium and strontium and the trace elements iron, manganese, copper and zinc. The chemical composition of the crystal matrix is unusual. B. azoricus is identified as a species having one of the most strontium impoverished shells amongst the marine molluscs. For a bimineral species the magnesium concentration is also extraordinary low. Despite originating from a trace metal rich environment; the metal concentrations in the shells were exceptionally low. Mean concentrations of iron, manganese, copper and zinc were 20.6, 3.7, 0.6 and 9.4 $\mathrm{gg} \mathrm{g}^{-1}$ respectively. Minor and trace element concentrations exhibited a marked intrapopulation variability. Copper concentrations increased and iron and zinc concentrations decreased with increasing shell weight. Due to its insensitivity to the high environmental levels of trace elements and the variability in intra-population concentrations induced by shell weight the crystal matrix of the shell of $B$. azoricus has little potential for use in environmental trace metal monitoring in areas contiguous to deep-sea hydrothermal vents.
\end{abstract}

(C) 2007 Elsevier Ltd. All rights reserved.

Keywords: Metals; Shells; Bathymodiolus azoricus; Hydrothermal vent field

\section{Introduction}

Hydrothermal vents, first observed at the Galapagos Ridge in the East Pacific Ocean in 1977 are very unusual environments (Little and Vrijenhoek, 2003; van Dover and Lutz, 2004). Areas contiguous to the vents are extreme environments with respect to both the prevailing physical and chemical conditions. The waters are characterised by high temperature and pressure, low dissolved concentrations of oxygen and elevated dissolved concentrations of hydrogen sulphide, methane and carbon dioxide. Moreover, concentrations of toxic trace metals in the solution, colloidal and particulate phases are generally extremely high (Desbruyères et al., 2001; Douville et al., 2002).

\footnotetext{
* Corresponding author. Tel.: +351289 800900x7369; fax: +351289818353
} E-mail address: acravo@ualg.pt (A. Cravo).
Nevertheless, such areas are highly biologically productive (Rousse et al., 1997; Little and Vrijenhoek, 2003; van Dover and Lutz, 2004). Amongst the life forms associated with the chimneys of the hydrothermal sources the bivalve mussels (Bathymodiolus sp.) are normally found living in high densities (van Dover et al., 1996; von Cosel et al., 1999; Desbruyères et al., 2001; Hardivillier et al., 2004; Miyazaki et al., 2004).

A number of hydrothermal vent fields exist along the MidAtlantic Ridge in the vicinity of the Azores Triple Junction. Data on the physical and chemical properties of the water fluids in these areas are described by Fouquet et al. $(1995,1997)$, Charlou et al. (1997, 2000), Douville et al. (1997, 1999, 2002), Langmuir et al. (1997), von Damm et al. (1998), Sarradin et al. (1999). However significant spatial and temporal differences in both the physical and chemical conditions have been found at places where fauna live (Desbruyères et al., 2001). The fauna in 
the vicinity of these hydrothermal sources is dominated by the bivalve mussel Bathymodiolus azoricus (Colaço et al., 1998, 2002; Desbruyères et al., 2000, 2001; Company et al., 2004).

In view of the high and potentially toxic concentrations of metals present in hydrothermal vent areas attention has been given to metal concentrations accumulated in the soft tissues of a variety of associated fauna (Roesijadi and Crecelius, 1984; Roesijadi et al., 1985; Cosson-Mannevy et al., 1988; Smith and Flegal, 1989; Cosson and Vivier, 1997; Geret et al., 1998; Rousse et al., 1998; Company et al., 2004; Hardivillier et al., 2004). With respect to the molluscan fauna in the hydrothermal vent areas the high environmental trace metal concentrations will also influence the chemical assemblage associated with the shell. To date this aspect has received comparatively little attention (Roesijadi and Crecelius, 1984; Kádár and Costa, 2006).

The soft tissues of marine molluscs are generally more efficient accumulators of metals than shells (Brown and Depledge, 1998) and they have frequently been used to assess metal contamination of the aquatic environment. Similar studies using the shells are few although shells have several important practical advantages over the use of soft tissues (Cravo et al., 2002). When addressing the potential use of organisms as environmental indicators then, whether it be the soft tissues or the shells that are used, two preliminary considerations must be addressed. First, the specimens must be meticulously clean prior to analysis. If vestiges of surface contamination remain the specimens will ipso facto reflect the quality of the environment from which they were taken. Whilst obvious this consideration has not always been given the attention it deserves. Secondly, in order to draw meaningful conclusions from concentration data on specimens taken from different sites it is essential to first have an appreciation of both the magnitude and the causes of the intra-population heterogeneity in chemical concentration.

In view of the high concentrations of dissolved, colloidal and particulate trace metal concentrations in hydrothermal vent areas this paper addresses the cleaning problem and presents for the first time data on the chemical assemblage in the crystal matrix of the shell of a deep-sea hydrothermal mollusc, B. azoricus. These data are compared with the chemical assemblage of the crystal matrix in the shells of coastal analogues. The intra-population heterogeneity in the chemical composition of the crystal matrix of $B$. azoricus is presented and assessed with respect to evaluating the possible relevance of the shells of this species to environmental quality assessment in hydrothermal vent areas.

\section{Materials and methods}

\subsection{Study area and sampling}

Menez Gwen is one of the shallowest hydrothermal vents with a depth of $850 \mathrm{~m}$ (Company et al., 2004) occurring on the Mid-Atlantic Ridge, south west of the Azores Islands (Fig. 1). The precise location is given as $37^{\circ} 51^{\prime} \mathrm{N}, 31^{\circ} 31^{\prime}$ W. The chimneys here are small (Desbruyères et al., 2000) and water temperature range from $8^{\circ} \mathrm{C}$ to $30^{\circ} \mathrm{C}$ (von Cosel et al., 1999; VENTOX, 2003). At Menez Gwen B. azoricus is abundantly dispersed in the substratum occurring in densities ranging between 400 and 700 individuals $\mathrm{m}^{-2}$ (Colaço et al., 1998; Sarradin et al., 1999).

Specimens of the B. azoricus population at Menez Gwen were collected using the remote operated vehicle (ROV) "Victor6000" during the EU-funded ATOS cruise (June 22-July 21, 2001; Sarradin et al., 2001).

\subsection{Sample cleaning}

At the laboratory damaged or broken shells were rejected. The shells were washed in a jet of distilled water and scrubbed in distilled deionised water with a toothbrush to remove loosely attached biogenic and inorganic particles and dried at $80^{\circ} \mathrm{C}$ to constant weight. Prior to metal analysis each individual shell pair was subject to a further cleaning process designed to remove material that was not an integral component of the crystalline shell matrix (Foster and Chacko, 1995). These authors provided a detailed discourse on the analytical problems arising with respect to analysis of trace metals in shell material. These problems are briefly stressed here as they are of particular relevance to the analysis of B. azoricus shells.

The trace elements associated with a shell are distributed among three distinct phases: (a) elements which constitute an integral part of the crystalline matrix (b) for those shells with a periostracum trace elements may be either adsorbed to or present as structural components of this tissue and (c) trace

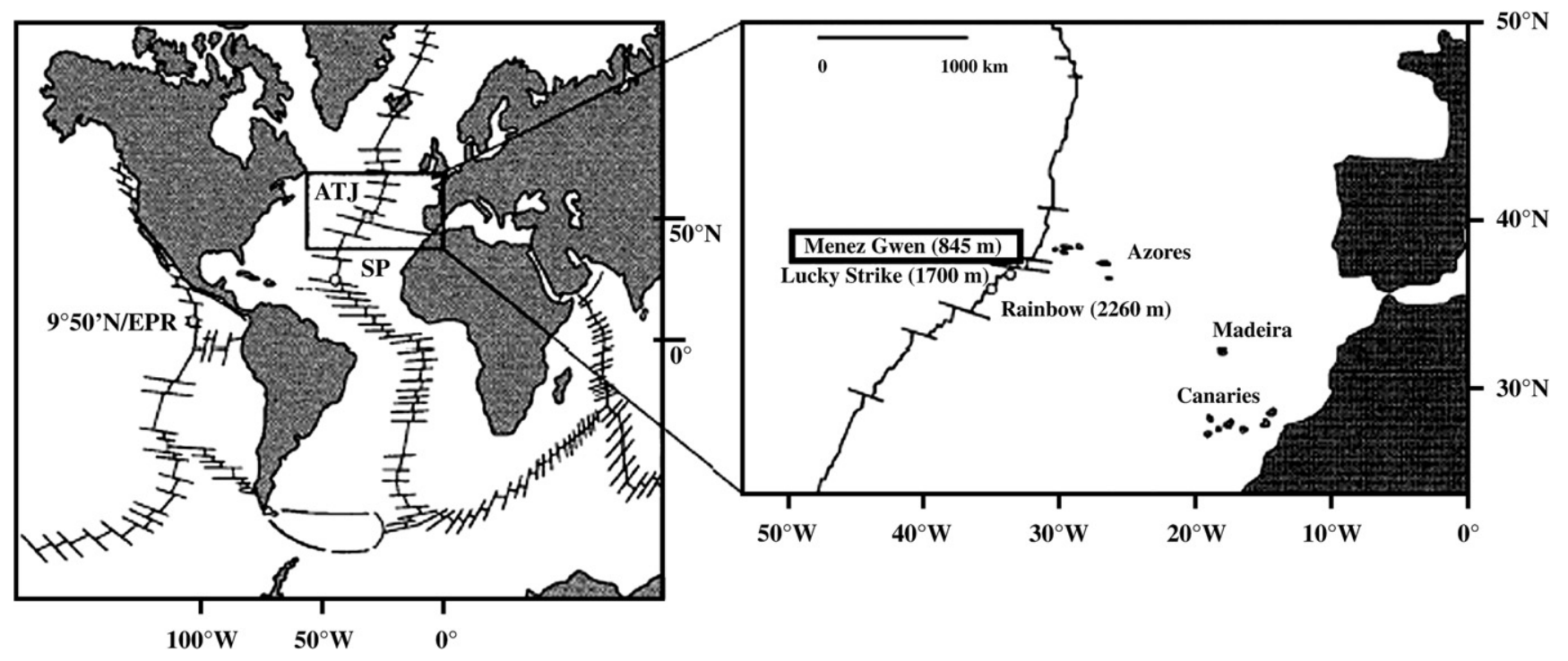

Fig. 1. Location of the Menez Gwen hydrothermal field in the Azores Triple Junction (adapted from Comtet et al., 2000). 
elements associated with the hydrous colloidal flocks and particulate matter which adhere to the shell surface. The periostracum can generally be considerably enriched in trace metals compared to the underlying crystal matrix. It is however, fragile and can be easily damaged or eroded either naturally in the environment or during the surface cleaning process prior to analysis. Retaining the periostracum on the shell for analysis introduces a variable (the degree of completeness of the periostracum layer) which cannot be quantified but which can have a considerable impact upon the analytical results. Material adhered to the shell surface will be rich in trace metals compared to the crystal matrix and unless the shell is meticulously cleaned, the metal concentrations that constitute an integral part of the shell matrix are likely to be grossly supplemented by surface contamination. Failure to remove all vestiges of (b) and (c) prior to analysis will lead to highly distorted and elevated concentrations with respect to those actually present as integral constituents of the crystalline shell matrix and mask, or indeed generate spurious relationships amongst the metal concentrations and growth characteristics, including the size and weight of the shell; which are both functions of surface area.

These considerations are pertinent to B. azoricus in so far as this species has a periostracum and the surface of the shell specimens from Menez Gwen were so contaminated with adhered hydrogenous material that the contamination was immediately visually obvious. In order to eliminate the vagaries of (b) and (c) above the shells taken from Menez Gwen, after being manually cleaned, were further cleaned by selective chemical attack (Foster and Chacko, 1995) to remove all material that was not an integral component of the crystalline shell matrix. Each shell was individually treated with $5 \% \mathrm{w} / \mathrm{v}$ hydrogen peroxide in the ratio $10 \mathrm{~mL} \mathrm{~g}^{-1}$ shell weight and gently heated at $60{ }^{\circ} \mathrm{C}$ for $48 \mathrm{~h}$. After rinsing with deionised distilled water, $0.005 \mathrm{M} \mathrm{HCl}$ was added, again in the ratio of $10 \mathrm{~mL} \mathrm{~g}^{-1}$ shell weight and left for $48 \mathrm{~h}$. For both these stages the shells were placed in vials of appropriate diameter to ensure that the reagents covered and therefore reacted with the entire surface of the shell. The shells were then washed in distilled deionised water and oven dried. The effect of the selective chemical attack is illustrated in Fig. 2. Subsequent to the treatment the shells of B. azoricus were a uniform brilliant white. Each shell pair was then pulverised in an agate mortar and the resulting homogenous fine powder stored for subsequent analysis.

\subsection{Analytical procedure}

Duplicate samples of each shell $(0.1 \mathrm{~g})$ were totally digested in a mixture of concentrated nitric acid and 50\% w/v hydrogen peroxide. After evaporation to dryness, the residue was redissolved in $2 \mathrm{~mL}$ of concentrated hydrochloric acid and fumed to dryness. The final residue was redissolved in $10 \mathrm{~mL}$ of $0.05 \mathrm{M}$ hydrochloric acid. Subsamples of this digest were taken for the analysis of $\mathrm{Mg}$, $\mathrm{Sr}, \mathrm{Fe}, \mathrm{Mn}, \mathrm{Zn}$ and $\mathrm{Cu}$ by flame atomic absorption spectrophotometry (PerkinElmer, model Analyst 800). All analyses were calibrated against analytical

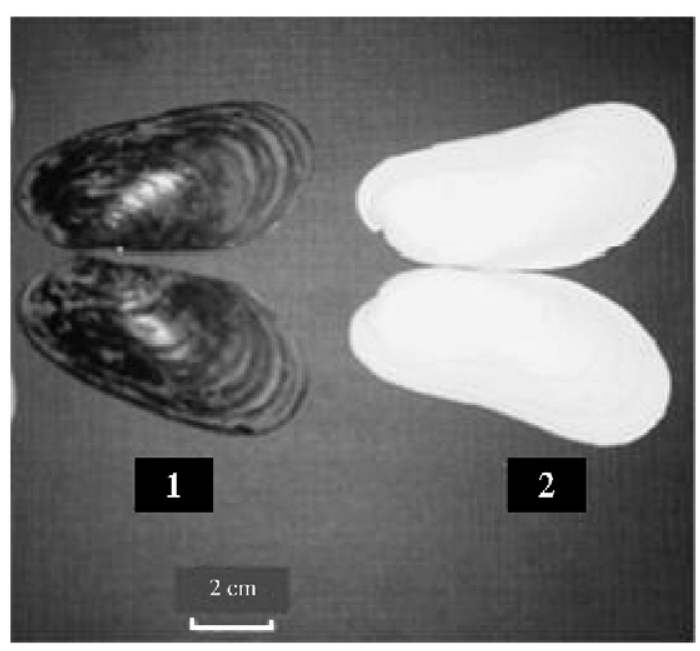

Fig. 2. Image of shells: 1-after being washed and scrubbed; 2-after the chemical attack
Table 1

Summary data for shells of B. azoricus $(n=21)$ from the Menez Gwen hydrothermal vent

\begin{tabular}{lcccc}
\hline Variable & Average \pm S.E. & Min & Max & $\% \mathrm{CV}$ \\
\hline Weight $(\mathrm{g})$ & $1.75 \pm 0.12$ & 0.62 & 2.63 & 33 \\
Shell length $(\mathrm{mm})$ & $44.3 \pm 1.7$ & 27.4 & 54.8 & 17 \\
$\mathrm{Mg}\left(\mu \mathrm{g} \mathrm{g}^{-1}\right)$ & $458 \pm 17$ & 369 & 687 & 17 \\
$\mathrm{Sr}\left(\mu \mathrm{g} \mathrm{g}^{-1}\right)$ & $871 \pm 26$ & 536 & 1078 & 14 \\
$\mathrm{Mg} / \mathrm{Sr}^{-1}$ & $0.53 \pm 0.02$ & 0.39 & 0.76 & 17 \\
$\mathrm{Fe}\left(\mu \mathrm{g} \mathrm{g}^{-1}\right)$ & $20.6 \pm 0.7$ & 15.6 & 27.7 & 16 \\
$\mathrm{Mn}\left(\mu \mathrm{g} \mathrm{g}^{-1}\right)$ & $3.7 \pm 0.7$ & 0.1 & 10.7 & 84 \\
$\mathrm{Zn}\left(\mu \mathrm{g} \mathrm{g}^{-1}\right)$ & $9.4 \pm 0.7$ & 4.1 & 15.4 & 34 \\
$\mathrm{Cu}\left(\mu \mathrm{g} \mathrm{g}^{-1}\right)$ & $0.6 \pm 0.1$ & 0.1 & 1.4 & 79 \\
\hline
\end{tabular}

standards containing the stoichiometric equivalent of spectrographically pure calcium carbonate ( $\mathrm{HCl}$ digested) as the samples being analysed and the samples were batch-analysed in random sequence with respect to the original weight of the shell specimens in order to remove any analytical bias from the intrapopulation study.

In the absence of an analytical reference material for marine biogenic carbonate all analyses were calibrated against an internal reference standard consisting of a homogeneous fine powder of the shells of five cleaned specimens of $B$. azoricus. The mean concentrations in $\mu \mathrm{g} \mathrm{g}^{-1}$ ( \pm standard error) from 10 individual analyses of this powder were: $\mathrm{Mg}$ : $473 \pm 2.5$, Sr: $868 \pm 7.3$; Fe: $20.9 \pm$ $1.0 ; \mathrm{Mn}: 4.0 \pm 0.2 ; \mathrm{Zn}: 9.3 \pm 0.2$; $\mathrm{Cu}: 0.7 \pm 0.1$.

\subsection{Statistical analysis}

The coefficient of correlation $(r)$ between variables was calculated at a level of significance of $99 \%$. Principal component analysis (PCA) was applied to the data matrix of shell weight and the measured concentrations of the minor and trace elements to provide insight into the factors propagating the intrapopulation heterogeneity.

\section{Results and discussion}

\subsection{Intra-population variability}

Few studies addressing the heterogeneity in chemical composition amongst shells within the population of an individual species collected from a single location exist. Those that have been reported relate to Patellidae species (Foster and Chacko, 1995; Cravo et al., 2002) and species of the Neritidae (Foster et al., 1997). Data on the heterogeneity of metal concentrations in 21 specimens of B. azoricus from the Menez Gwen vent site are given in Table 1.

Of the minor elements associated with the shells of the Menez Gwen population strontium was consistently present in much higher concentrations than magnesium. The variability of strontium and magnesium concentrations from shell to shell is illustrated in Figs. 3 and 4 respectively. The $\% \mathrm{CV}$ (standard deviation/mean $\times 100$ ) for strontium and magnesium were of similar magnitude (14\% and $17 \%$ respectively). Of the 21 specimens analysed, 14 had a strontium concentration within $\pm 10 \%$ of the mean $\left(871 \mu \mathrm{g} \mathrm{g}^{-1}\right)$ and of the outliers the maximum deviations from the mean were $-38 \%$ and $+24 \%$. For magnesium, 13 shells had concentrations within $\pm 10 \%$ of the mean $\left(458 \mu \mathrm{g} \mathrm{g}^{-1}\right)$ and here the maximum deviations of the outliers from the mean were $-19 \%$ and $+50 \%$.

Differences in both strontium and magnesium concentrations from shell to shell led to a range in the magnesium to strontium ratio amongst the population. About the mean of 0.53 some shells showed preferential magnesium enrichment, the ratio increasing to a maximum of 0.76 . Others exhibited preferential strontium enrichment, the ratio decreasing to a minimum of 0.39 . 


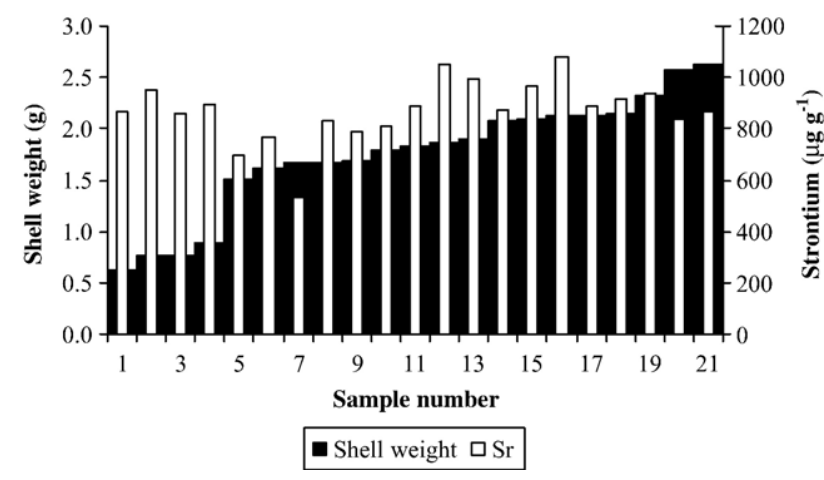

Fig. 3. Shell weight $(\mathrm{g})$ and strontium concentrations $\left(\mu \mathrm{g} \mathrm{g}^{-1}\right)$ in each of the 21 specimens of $B$. azoricus from Menez Gwen.

Of the four trace metals analysed iron was consistently present in the highest concentration (Table 1). Iron also exhibited the lowest variability (Fig. 4). The \%CV (16\%) was of a magnitude similar to that of the two minor elements magnesium and strontium. Of the 21 specimens analysed 20 had iron concentrations within $\pm 25 \%$ of the mean $\left(20.6 \mu \mathrm{g} \mathrm{g}^{-1}\right)$. The single outlier concentration was $27.7 \mu \mathrm{g} \mathrm{g}^{-1}$, exceeding the mean by $34 \%$.

The analytical problems with respect to trace metal concentrations in the shell of B. azoricus were mentioned in the Materials and methods section. Failure to adequately solve these problems would be immediately apparent in the concentration data generated for iron. The coherence of the iron data (Table 1; Fig. 4) attests to the efficacy of the sample cleaning procedure adopted.

Zinc concentrations were both lower and exhibited a greater $\% \mathrm{CV}$ than those of iron (Table 1). Of the 21 specimens only 9 had zinc concentrations within $\pm 25 \%$ of the mean $\left(9.4 \mu \mathrm{g} \mathrm{g}^{-1}\right)$. The maximum deviations of the outliers from the mean were $-56 \%$ and $+64 \%$. The two remaining trace metals $(\mathrm{Cu}$ and $\mathrm{Mn})$ were both in significantly lower concentrations than iron and zinc. Both elements also displayed high $\% \mathrm{CV}$ reaching a maximum for manganese.

A linear least squares correlation matrix amongst the variables of shell weight and the measured concentrations of the minor and trace elements produced only one correlation of significance at the $99 \%$ level of confidence, namely that between strontium and magnesium $(r=0.55)$. A principal component analysis of the same data matrix gave more insight into the factors influencing the chemical assemblages in the shells of the Menez Gwen population (Table 2). Two major axes accounted for about $60 \%$ of the total variance. The loadings and covariations of the predominant characteristics acting on the second major axis relate to the contemporaneous influx of magnesium and strontium into the shell matrix by diadochically replacing the calcium ion. The importance of this process will be addressed later. The principal axis, accounting for $33 \%$ of the variance, had significant loadings attached to the weight of the shell and the concentrations of the elements iron, copper and zinc. The covariance on this axis indicates a tendency for copper concentrations to increase with increasing weight of the shell. In contrast iron and zinc concentrations decrease with increasing shell weight.

\subsection{Magnesium and strontium concentrations}

Shell formation involves the deposition of calcium carbonate in the form of calcite or aragonite and certain molluscs have shells constructed of a mixture of both polymorphs. The shells of Mytilus species are of mixed mineralogy (Wilbur, 1972; Milliman, 1974;

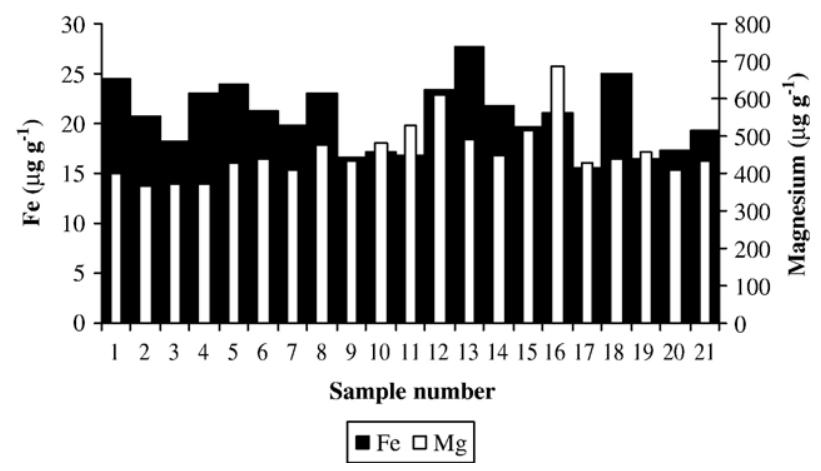

Fig. 4. Magnesium and iron concentrations $\left(\mu \mathrm{gg}^{-1}\right)$ in each of the 21 specimens of $B$. azoricus from Menez Gwen.

Lowenstam and Weiner, 1989). Consistent with the Mytilidae the shell of B. azoricus is also of mixed mineralogy (Kádár and Costa, 2006) and aragonite is the predominant polymorph (F. Rocha, pers. comm. 2006).

Cations other than calcium are also incorporated into the crystal lattice. If the rules of crystal stereochemistry are considered without invoking any biological mediation in skeletal formation the influx of these ions into the crystal matrix of shells of marine origin is easy to predict. Magnesium and strontium are major conservative constituents of seawater. They are readily available as the $\mathrm{Mg}^{2+}$ ion (ionic radius $0.066 \mathrm{~nm}$ ) and the $\mathrm{Sr}^{2+}$ ion (ionic radius $0.112 \mathrm{~nm}$ ) to diadochically replace the $\mathrm{Ca}^{2+}$ ion (ionic radius $0.099 \mathrm{~nm}$ ) in the crystal matrix of the shell. Consequently in marine shells magnesium and strontium, after calcium, are by far the two most predominant cations incorporated into the shell. Moreover, the extent to which these two elements are able to invade the crystal matrix of the shell of a particular species provides an indication of the relative ease by which other $2+$ cations, particularly polluting trace metals, may also invade the shell matrix.

The concentration of magnesium in the shell of marine molluscs varies greatly from species to species. This vast range is primarily due to differences in skeletal mineralogy (Harriss, 1965). Magnesium, with an ionic radius less than calcium, forms a hexagonal carbonate isostructural with calcite. On purely steric grounds it is much more difficult for magnesium ions to be incorporated into marine mollusc shells composed of orthorhombic aragonite rather than hexagonal calcite. In general aragonitic shells have low magnesium concentrations within the range 90 to $500 \mu \mathrm{g} \mathrm{g}^{-1}$ (Foster and Cravo, 2003). In contrast calcitic shells exhibit much higher concentrations over a wider range. In Pecten species Turekian and Armstrong (1960) found

Table 2

Principal component analysis for the B. azoricus population from Menez Gwen $(n=21)$

\begin{tabular}{llll}
\hline & Axis 1 & Axis 2 & Axis 3 \\
\hline \% Variance & 33.2 & 25.7 & 20.1 \\
Eigenvalue & 2.3 & 1.8 & 1.4 \\
$\begin{array}{l}\text { Dominant characteristics } \\
\quad \text { Weight }\end{array}$ & +0.70 & & \\
$\quad$ Magnesium & & -0.90 & \\
$\quad$ Strontium & & -0.78 & \\
$\quad$ Iron & -0.72 & & -0.95 \\
$\quad$ Manganese & & & \\
$\quad$ Zinc & -0.83 & & \\
$\quad$ Copper & +0.76 & & \\
\hline
\end{tabular}


Table 3

Comparison of the trace metal concentrations $\left(\mu \mathrm{g} \mathrm{g}^{-1}\right)$ in the shells of M. edulis, $B$. azoricus and mollusc species $(n=59)$ from the coastal waters of East Africa

\begin{tabular}{|c|c|c|c|c|c|}
\hline Species & $\mathrm{Fe}$ & $\mathrm{Mn}$ & $\mathrm{Zn}$ & $\mathrm{Cu}$ & References \\
\hline \multirow[t]{9}{*}{ Mytilus edulis } & $<10$ & $<1$ & $<100$ & 3 & $\begin{array}{l}\text { Brooks and Rumsby } \\
\text { (1965) }\end{array}$ \\
\hline & $\begin{array}{l}6.4- \\
49\end{array}$ & NA & $\begin{array}{l}0.3- \\
39\end{array}$ & NA & $\begin{array}{l}\text { Bertine and Goldberg } \\
\text { (1972) }\end{array}$ \\
\hline & 32.4 & 8.2 & 3.8 & 6.3 & $\begin{array}{l}\text { Roesijadi and } \\
\text { Crecelius (1984) }\end{array}$ \\
\hline & 50 & 99.4 & 9.5 & 3.2 & $\begin{array}{l}\text { Szefer and Szefer } \\
(1990)\end{array}$ \\
\hline & $\begin{array}{l}13.8- \\
81.6\end{array}$ & $\begin{array}{l}25.5- \\
69.4\end{array}$ & $\begin{array}{l}3.5- \\
5.2\end{array}$ & $\begin{array}{l}6.1- \\
6.6\end{array}$ & Szefer et al. (2002) \\
\hline & 290 & 3.6 & 0.04 & 2.0 & Segar et al. (1971) \\
\hline & $\begin{array}{l}240- \\
1040\end{array}$ & $\begin{array}{l}5.7- \\
43\end{array}$ & $\begin{array}{l}11.4- \\
17.8\end{array}$ & $\begin{array}{l}16.4- \\
29.8\end{array}$ & Giusti et al. (1999) \\
\hline & $\begin{array}{l}300- \\
2600\end{array}$ & NA & NA & $\begin{array}{l}30- \\
160\end{array}$ & $\begin{array}{l}\text { Al-Dabbas et al. } \\
\text { (1984) }\end{array}$ \\
\hline & $\begin{array}{l}500- \\
5100\end{array}$ & $\begin{array}{l}100- \\
130\end{array}$ & $\begin{array}{l}9.2- \\
10.2\end{array}$ & $\begin{array}{l}0.07- \\
0.15\end{array}$ & $\begin{array}{l}\text { Szefer and Szefer } \\
(1985)\end{array}$ \\
\hline \multirow[t]{2}{*}{$\begin{array}{l}\text { Bathymodiolus } \\
\text { azoricus }\end{array}$} & $\begin{array}{l}15.6- \\
27.7\end{array}$ & $\begin{array}{l}0.1- \\
10.7\end{array}$ & $\begin{array}{l}4.1- \\
15.4\end{array}$ & $\begin{array}{l}0.1- \\
1.4\end{array}$ & Present study \\
\hline & 280 & NA & 31.2 & 80 & $\begin{array}{l}\text { Kádár and Costa } \\
\text { (2006) }\end{array}$ \\
\hline 59 coastal species & $\begin{array}{l}7.2- \\
30.6\end{array}$ & $\begin{array}{l}1.8- \\
16.4\end{array}$ & $\begin{array}{l}0.8- \\
7.2\end{array}$ & $\begin{array}{l}0.6- \\
4.1\end{array}$ & $\begin{array}{l}\text { Foster and Cravo } \\
(2003)\end{array}$ \\
\hline
\end{tabular}

$\mathrm{NA}=$ not analysed.

magnesium concentrations up to $4700 \mu \mathrm{g} \mathrm{g}^{-1}$. Afaj and Elewe (1989) give a range of 1906 to $6144 \mu \mathrm{g} \mathrm{g}^{-1}$ in the shell of Crassostrea cucullata. In Patella aspera (Cravo et al., 2002) and Patella vulgata (Foster and Chacko, 1995) magnesium concentrations ranged from 4605 to 4691 and 3528 to $3757 \mu \mathrm{g} \mathrm{g}^{-1}$ respectively. In species with bimineral shells the magnesium concentrations are of intermediate values tending to the characteristics of one polymorph or the other depending on the relative amounts of calcite and aragonite contributing to the shell structure.

Reference to Table 1 shows that the mean magnesium concentration in the bimineral shells of $B$. azoricus taken from Menez Gwen was $458 \mu \mathrm{g} \mathrm{g}^{-1}$. This value is surprisingly low and is within the range of concentrations found for the shells of marine species of mollusc with purely aragonitic shells. The low magnesium concentration has implications for the likely incorporation of other $2+$ cations such as $\mathrm{Fe}^{2+}, \mathrm{Mn}^{2+}, \mathrm{Cu}^{2+}$ and $\mathrm{Zn}^{2+}$ into the crystal matrix of the shell. These cations, like magnesium, have ionic radii less than calcium and always form hexagonal carbonates isostructural with calcite. In view of the low magnesium concentrations in the shell of B. azoricus it would be unreasonable to expect, on the grounds of crystal stereochemistry, anything other than very low concentrations of iron, copper, manganese and zinc to be incorporated into their shells even in extremely polluted waters.

The ionic radius of strontium $(0.112 \mathrm{~nm})$ is higher than that of calcium $(0.099 \mathrm{~nm})$ and it forms an orthorhombic carbonate isostructural with aragonite. In contrast to magnesium, mineralogy plays only a secondary role in controlling the strontium concentration associated with the shell of marine molluscs (Harriss, 1965). Although strontium is generally found in higher concentrations in aragonite than in calcitic shells, the range of concentrations found in both types of calcium carbonate is similar (950 to $3500 \mu \mathrm{g} \mathrm{g}^{-1}$ ). The mean strontium concentration in the shell of $B$. azoricus was $871 \mu \mathrm{g} \mathrm{g}^{-1}$. This is extraordinary low and B. azoricus is identified as a species having one of the most strontium impoverished shells amongst the marine molluscs. Lower concentrations have only been observed in specimens of Conus tessulatus $\left(822 \mu \mathrm{g} \mathrm{g}^{-1}\right)$ by Foster and Cravo (2003) and in C. cucullata (663 to $779 \mu \mathrm{g} \mathrm{g}^{-1}$ ) by Afaj and Elewe (1989). The low concentration of strontium in the shell has implications for the influx of other $2+$ cations with ionic radii greater than calcium such as lead and cadmium which also form orthorhombic carbonates.

\subsection{The trace metals}

Data in the literature on the trace metal concentrations in shells are striking by virtue of the apparently very large differences in concentration that can exist between species. In the case of iron for example the compilation by Milliman (1974) gives a concentration range of 30 to $300 \mu \mathrm{g} \mathrm{g}^{-1}$ amongst the Conidae, 30 to $700 \mu \mathrm{g} \mathrm{g}^{-1}$ for the Cerithiidae and 12 to $800 \mu \mathrm{g} \mathrm{g}^{-1}$ amongst the Littorinidae. The diversity amongst the Mytillidae is more dramatic even when data are only considered for an individual species. Literature data from various authors on the concentrations of iron, manganese, copper and zinc associated with the shell of Mytilus edulis are compared in Table 3. Also shown are the concentrations of these elements found in the crystal matrix of B. azoricus in the present work and these are compared with the recent data of Kádár and Costa (2006) on the concentrations in the shell of the same species taken from two hydrothermal fields (Menez Gwen and Lucky Strike) along the Mid-Atlantic Ridge together with data on the range of concentrations of trace elements found in the crystal matrix of fifty nine molluscan species from the coast of East Africa (Foster and Cravo, 2003).

Reference to Table 3 shows that the concentrations of iron, manganese, copper and zinc in the shell of $M$. edulis all vary over a considerable range. The variability is most evident with respect to iron. Brooks and Rumsby (1965) quote shell concentrations of iron of less than $10 \mu \mathrm{g} \mathrm{g}^{-1}$, while Bertine and Goldberg (1972), Roesijadi and Crecelius (1984) and Szefer and Szefer (1990) all report concentrations less than $60 \mu \mathrm{g} \mathrm{g}^{-1}$. At the other end of the scale Giusti et al. (1999) give concentrations reaching $1040 \mu \mathrm{g} \mathrm{g}^{-1}$, Al-Dabbas et al. (1984) report concentrations up to $2600 \mu \mathrm{g} \mathrm{g}^{-1}$ and Szefer and Szefer (1985) record a maximum concentration of $5100 \mu \mathrm{g} \mathrm{g}^{-1}$. Quoted manganese concentrations range from $<1$ to $130 \mu \mathrm{g} \mathrm{g}^{-1}$, zinc 0.04 to $39 \mu \mathrm{g} \mathrm{g}^{-1}$ and copper 0.07 to $160 \mu \mathrm{g} \mathrm{g}^{-1}$.

On such evidence it is easy to conclude that shells are particularly sensitive to environmental levels of exposure and could be valuable for monitoring heavy metal contamination in the marine environment. Conversely, the apparent variability in shell composition can often be traced to non-uniform cleaning and treatment procedures before shell digestion and analysis (Babukutty and Chacko, 1992; Foster and Chacko, 1995). This is dramatically demonstrated in Table 3 by a comparison of the data on B. azoricus. The concentrations of iron, manganese and zinc associated with the shells of B. azoricus reported by Kádár and Costa (2006) are very much higher than those found in the present study. The large difference can be accounted for by the sample cleaning and treatment procedures adopted prior to analysis. In the present study, as detailed in the Materials and methods section, the shells were subjected to selective chemical attack to remove all vestiges of surface contamination and the periostracum. The data given in Table 3 relate to the concentrations of iron, manganese, copper and zinc which are integral constituents of the crystal matrix of the shells. In contrast the concentration data given by Kádár and Costa (2006) relate to the whole shell. These authors report that $30 \%$ of the total iron, and $6 \%$ of both the total copper and zinc was reversibly bound to the outer surface of the shell and concentrations of iron, manganese and zinc in 
the periostracum were of the order of 250,60 and $40 \mu \mathrm{g} \mathrm{g}^{-1}$ respectively. In view of the high concentration of trace metals associated with the whole shell the authors conclude that the shells of $B$. azoricus are good environmental indicators. This may well be so but very large proportions of the metals associated with the whole shell are to be found attached to the outer surface and are not integral components of the crystal matrix.

It is clear from Table 3 that the trace metal concentrations in the crystal matrix of the shell of B. azoricus, although taken from a trace metal rich environment, are low when compared with analysis performed on the whole shell of its coastal water analogue M. edulis. Moreover, when compared with the range of concentrations found in the crystal matrices of the shells of fifty nine species taken from the relatively clean coastal waters of East Africa (Table 3) the trace metal assemblage in the crystal matrix of the shell of B. azoricus taken from Menez Gwen shows no particular enhancement. This insensitivity of the crystal matrix to elevated environmental concentrations of trace metals is not unprecedented. Foster and Chacko (1995) observed that the trace metal concentrations in the crystal matrix of the shell of $P$. vulgata taken from an extremely trace metal rich acid mine estuary were no greater than those in the crystal matrices of the same species taken from more pristine coastal environments. This observation led the authors to reject the shell of $P$. vulgata for potential use in environmental trace metal monitoring. On the evidence presented above it is difficult not to reach the same conclusion with respect to the shell of B. azoricus.

\section{Conclusions}

The data presented in Table 1 identify B. azoricus as a species having one of the most strontium impoverished shell amongst the marine molluscs. For a bimineral species the magnesium concentration is also extraordinary low. The difficulty that those two major conservative elements in the seawater have in invading the shell of B. azoricus is mimicked by the trace metals. Concentrations of iron, manganese, copper and zinc in the shell are all low. The concentrations of these trace elements recorded in the shell result from the combined influence of three predominant factors:

(a) The concentration levels in the shell will in some way reflect the bioavailability of the trace elements in their immediate environment.

(b) The range of iron, zinc and copper concentrations within the population and their mean concentrations are a function of the weight of the shells. The intra-population heterogeneity in B. azoricus showed that during the formative stages of shell growth zinc and iron were selectively incorporated into the crystal matrix while copper was selectively rejected. The addition of new material during subsequent growth was less rich in zinc and iron promoting a progressive dilution of the formative high concentrations. Conversely, new material was richer in copper leading to a progressive increase of the formative low concentrations.

(c) B. azoricus is a bimineral species. The ease by which the trace metals invade the crystal matrix depends upon the relative proportions of the calcite and aragonite polymorphs in the assemblage. Differences in the relative proportions of the polymorphs from shell to shell within the population will generate differences in the concentrations of the trace metals.

In view of the insensitivity of the shell to the high metal levels in the hydrothermal environment it is likely that any differences in the trace metal assemblage in the shell of $B$. azoricus populations taken from different hydrothermal vent fields along the Mid-Atlantic Ridge may well be more of a reflection of intra-population heterogeneities generated by (b) and (c) above than by gross differences in exposure levels.

\section{Acknowledgments}

The authors gratefully acknowledge Angela Serafim for transporting the samples of shells from Azores. We also wish to thank Dr. Fernando Rocha, Department of Geology at the University of Aveiro for the qualitative X-ray diffraction analysis of the shells.

The authors also would like to thank Pierre-Marie Sarradin, Chief Scientist of ATOS cruise and David Dixon, VENTOX (EVK3 CT1999-00003) project coordinator and the crew of N/ O Atalante and Victor 6000 (IFREMER). Rui Company was funded by a grant from Fundação para a Ciência e a Tecnologia (Ph.D. grant SFRH/BD/904/2000) of the Ministry of Science and Technology of Portugal.

\section{References}

Afaj AH, Elewe AH. Trace element distribution in mollusc shells from Khor AlZubair. J Biol Sci Res 1989;20(3):581-90.

Al-Dabbas MAM, Hubbard FH, McManus J. The shell of Mytilus as an indicator of zonal variations of water quality within an estuary. Estuar Coas Shelf Sci 1984;18:263-70.

Babukutty Y, Chacko J. Trace metals in an estuarine bivalve from the southwest coast of India. AMBIO 1992;21:292-6.

Bertine KK, Goldberg ED. Trace metals in clams, mussels and shrimp. Limnol Oceanogr 1972;17(6):877-84.

Brooks RR, Rumsby MG. The biochemistry of trace element uptake by some New Zealand bivalves. Limnol Oceanogr 1965;10:521-7.

Brown MT, Depledge MH. Determinants of trace metal concentrations in marine organisms. In: Langston W, Bebianno MJ, editors. Metal metabolism in aquatic environments. London: Chapman and Hall; 1998 p. $185-217$.

Charlou JL, Donval J-P, Douville E, Knoery J, Fouquet Y, Bougault H, et al. High methane flux between $15^{\circ} \mathrm{N}$ and the Azores Triple Junction, MidAtlantic Ridge. Hydrothermal and serpentinization processes. Eos Trans Am Geophys Union 1997;78(46):F831.

Charlou JL, Donval JP, Douville E, Jean-Baptiste P, Radford-Knoery J, Fouquet $\mathrm{Y}$, et al. Compared geochemical signatures and the evolution of Menez Gwen $\left(37^{\circ} 50^{\prime} \mathrm{N}\right)$ and Lucky Strike $\left(37^{\circ} 17^{\prime} \mathrm{N}\right)$ hydrothermal fluids, south of the Azores Triple Junction on the Mid-Atlantic Ridge. Chem Geol 2000;171 $(1-2): 49-75$.

Colaço A, Desbruyères D, Comtet T, Alayse AM. Ecology of the Menez Gwen hydrothermal vent field (Mid-Atlantic Ridge/Azores Triple Junction). Cah Biol Mar 1998;39:237-40.

Colaço A, Dehairs F, Desbruyères D. Nutritional relations of deep-sea hydrothermal fields at the Mid-Atlantic Ridge: a stable isotope approach. Deep-Sea Res Part I Oceanogr Res Pap 2002;49(2):395-412.

Company R, Serafim A, Bebianno MJ, Cosson R, Shillito B, Fiala-Médioni A. Effect of cadmium, copper and mercury on antioxidant enzyme activities and lipid peroxidation in the gills of the hydrothermal vent mussel Bathymodiolus azoricus. Mar Environ Res 2004;58:377-81. 
Comtet T, Jollivet D, Segonzac M, Dixon DR. Molecular and morphological identification of settlement-stage vent mussel larvae, Bathymodiolus azoricus (Bivalvia: Mytilidae), preserved in situ at active vent fields on the Mid-Atlantic Ridge. Limnol Oceanogr 2000;45(7):1655-61.

Cosson RP, Vivier J-P. Interaction of metallic elements and organisms within hydrothermal vents. Cah Biol Mar 1997;38:43-50.

Cosson-Mannevy M-A, Cosson RP, Gaill F, Laubier L. Transfert, accumulation et régulation des éléments minéraux chez les organismes des sources hydrothermales. Actes du Colloque Hydrothermalisme, Biologie et Écologie. Oceanol Acta 1988;8:219-26.

Cravo A, Foster P, Bebianno MJ. Minor and trace elements in the shell of Patella aspera (Röding 1798). Environ Int 2002;28(4):295-302.

Desbruyères D, Almeida A, Biscoito M, Comtet T, Khripounoff A, Le Bris N, et al. A review of the distribution of hydrothermal vent communities along the northern Mid-Atlantic Ridge: dispersal vs. environmental controls. Hydrobiologia 2000;440:201-16.

Desbruyères D, Biscoito $\mathrm{M}$, Caprais J-C, Colaço $\mathrm{A}$, Comtet $\mathrm{T}$, Crassous $\mathrm{P}$, et al. Variations in deep-sea hydrothermal vent communities on the Mid-Atlantic Ridge near the Azores plateau. Deep-Sea Res Part I Oceanogr Res Pap 2001;48:1325-46.

Douville E, Charlou JL, Donval JP, Knoery J, Fouquet Y, Bienvenu P, et al. Trace elements in fluids from the new Rainbow hydrothermal field $\left(36^{\circ} 14 \mathrm{~N}^{\prime}\right.$, MAR): a comparison with other Mid-Atlantic Ridge fluids. Eos Trans - Am Geophys Union 1997;78(46):F832.

Douville E, Bienvenu P, Charlou JL, Donval JP, Fouquet Y, Appriou P, et al. Yttrium and rare earth elements in fluids from various deep-sea hydrothermal systems. Geochim Cosmochim Acta 1999;63(5):627-43.

Douville E, Charlou JL, Oelkers EH, Bienvenu P, Jove Colon CF, Donval JP, et al. The Rainbow vent fluids $\left(36^{\circ} 14^{\prime} \mathrm{N}, \mathrm{MAR}\right)$ : the influence of ultramafic rocks and phase separation on trace metal content in Mid-Atlantic Ridge hydrothermal fluids. Chem Geol 2002;184:37-48.

Foster P, Chacko J. Minor and trace elements in the shell of Patella vulgata (L.). Mar Environ Res 1995;40:55-76.

Foster P, Cravo A. Minor elements and trace metals in the shell of marine gastropods from a shore in tropical East Africa. Water Air Soil Pollut 2003;145:53-65.

Foster P, Chacko J, Badran MI. Minor and trace concentrations in the shells of four Nerita species ( $N$. albicilla, $N$. costata, N. polita, N. undata) from Ko Phuket, Thailand. J Mar Atmos Res 1997;1(1):25-32.

Fouquet Y, Ondréas H, Charlou JL, Donval JP, Radford-Knoery J, Costa I, et al. Atlantic lava lakes and hot vents. Nature 1995;377:201.

Fouquet Y, Charlou JL, Ondréas H, Radford-Knoery J, Donval JP, Douville E, et al. Discovery and first submersible investigations on the Rainbow hydrothermal field on the Mar $\left(36^{\circ} 14^{\prime} \mathrm{N}\right)$. Eos Trans - Am Geophys Union 1997;78(46): F832.

Geret F, Rousse N, Riso R, Sarradin P-M, Cosson RP. Metal compartmentalization and metallothionein isoforms in mussels from the Mid-Atlantic Ridge, preliminary approach to the fluid-organism relationship. Cah Biol Mar 1998;29:291-3.

Giusti L, Williamson AC, Mistry A. Biologically available trace metals in Mytilus edulis from the coast of northeast England. Environ Int 1999;25 (8):968-81.

Hardivillier Y, Leignel V, Denis F, Uguen G, Cosson R, Laulier M. Do organisms living around hydrothermal vent sites contain specific metallothioneins? The case of the genus Bathymodiolus (Bivalvia, Mytilidae). Comp Biochem Physiol C Comp Pharmacol 2004;139(1-3):111-8.

Harriss RC. Trace element distribution in molluscan skeletal material I. Magnesium, iron, manganese, and strontium. Bull Mar Sci 1965;15:265-73.

Kádár E, Costa V. First report on the micro-essential metal concentrations in bivalve shells from deep-sea hydrothermal vents. J Sea Res 2006;56:37-44.

Langmuir C, Humphris S, Fornari D, Van Dover C, von Damm K, Tivey MK, et al. Hydrothermal vents near a mantle hot spot: the Lucky Strike vent field at $37^{\circ} \mathrm{N}$ on the Mid-Atlantic Ridge. Earth Planet Sci Lett 1997;148:69-91.
Little CTS, Vrijenhoek RC. Are hydrothermal vent animals living fossils. Trends Ecol Evol 2003;18(11):582-8.

Lowenstam HA, Weiner S. On biomineralization. Oxford: Oxford University Press; 1989. 324 pp.

Milliman JD. Marine carbonates. In: Milliman JD, Muller G, Forstner U, editors. Recent Sedimentary Carbonates, Part I. New York: Springer Verlag; 1974. p. 109-17.

Miyazaki J-I, Shintaku M, Kyuno A, Fujiwara Y, Hashimoto J, Iwasaki H. Phylogenetic relationships of deep-sea mussels of the genus Bathymodiolus (bivalvia: Mytilidae). Mar Biol 2004;144:527-35.

Roesijadi G, Crecelius EA. Elemental composition of the hydrothermal vent clam Calyptogena magnifica from the East Pacific Rise. Mar Biol 1984;83:155-61.

Roesijadi G, Young JS, Crecelius EA, Thomas LE. Distribution of trace metals in the hydrothermal vent clam, Calyptogena magnifica. Biol Soc Wash Bull 1985;6:311-24

Rousse N, Boulegue J, Geret F, Fiala-Medioni A. Bioaccumulation of metals and detoxification processes within hydrothermal vent molluscs: the case of the bivalve Bathymodiolus sp. from the Mid-Atlantic Ridge. Biol Deep Sea Hydrotherm Vents 1997;38:137-8.

Rousse N, Boulegue J, Cosson RP, Fiala-Medioni A. Bioaccumulation des métaux chez le mytilidae hydrothermal Bathymodiolus sp. de la ride médioatlantique. Oceanol Acta 1998;21:597-607.

Sarradin PM, Caprais JC, Riso R, Kerouel R, Aminot A. Chemical environment of the hydrothermal mussel communities in the Lucky Strike and Menez Gwen vent fields, Mid-Atlantic Ridge. Cah Biol Mar 1999;40:93-104.

Sarradin PM, Desbruyères D, Dixon D, Almeida A, Caprais JC, Colaço A, et al. ATOS cruise R/V l'Atalante, ROV Victor, June 22nd-July 21st 2001. InterRidge News 2001;10(2):18-20.

Segar DA, Collins JD, Riley JP. The distribution of the major and some minor elements in marine animals. Part II, Molluscs. J Mar Biol Assoc UK 1971;51:131-6.

Smith DR, Flegal AR. Elemental concentrations of hydrothermal vent organisms from Galápagos Rift. Mar Biol 1989;102:127-33.

Szefer P, Szefer K. Occurrence of ten metals in Mytilus edulis L. and Cardium glaucum L. from the Gdansk Bay. Mar Pollut Bull 1985;16:446-50.

Szefer P, Szefer K. Metals in molluscs and associated bottom sediments of the southern Baltic. Helgol Meeresunters 1990;44:411-24.

Szefer P, Frelek K, Szefer K, Lee Ch-B, Kim B-S, Warzocha J, et al. Distribution and relationships of trace metals in soft tissue, byssus and shells of Mytilus edulis trossulus from the southern Baltic. Environ Pollut 2002;120:423-44.

Turekian KK, Armstrong RL. Magnesium, strontium and barium concentrations and calcite:aragonite ratios of some recent molluscan shells. J Mar Res 1960;18:133-51.

van Dover CL, Lutz RA. Experimental ecology at deep-sea hydrothermal vents: a perspective. J Exp Mar Biol Ecol 2004;300(1-2):273-307.

van Dover CL, Desbruyères $\mathrm{D}$, Segonzac $\mathrm{M}$, Comtet $\mathrm{T}$, Saldanha L, FialaMedioni A, et al. Biology of the Lucky Strike hydrothermal field. Deep-Sea Res Part I Oceanogr Res Pap 1996;43(9):1509-29.

VENTOX. Deep-Sea hydrothermal vents: a natural pollution laboratory (EVK3 CT1999). Final Report 1 March 2000-28 February 2003.

von Cosel R, Comtet T, Krylova EM. Bathymodiolus (Bivalvia: Mytilidae) from hydrothermal vents on the Azores Triple Junction and the Logatchev hydrothermal field, Mid-Atlantic Ridge. Veliger 1999;4:218-48.

von Damm KL, Bray AM, Buttermore LG, Oosting SE. The geochemical controls on vent fluids from the Lucky Strike vent field, Mid-Atlantic Ridge. Earth Planet Sci Lett 1998;160(3-4):521-36.

Wilbur KM. Shell formation in mollusks. In: Florkin MP, Scheer BT, editors. Chemical Zoology, vol. VII. New York: Academic Press; 1972. p. 103-43. 